\title{
Ziyaret Etmeyenlerin Gözünde Turistik Bir Destinasyon Olarak Amasya
}

\author{
Amasya as a Tourist Destination From the Non-Visitors' Point of View
}

Burak ERYILMAZ*

\begin{abstract}
$\ddot{O} Z$
Imaj, bir destinasyonun pazarlama başarısı için oldukça önemlidir. Bir destinasyonun ziyaret edilme sebepleri arasında o destinasyonun sahip olduğu olumlu imaj sayllabileceği gibi ziyaret edilmeme gerekçesi de potansiyel ziyaretçilerin gözündeki olumsuz imaj olabilir. Bu çalışmada Amasya'yı daha önce ziyaret etmeyenlerin destinasyon imajlarının ve neden ziyaret etmediklerinin öğrenilmesi amaçlanmıştır. Amasya önemli bir tarih ve kültür geçmişine sahip, turizm potansiyeli yüksek ve ziyaretçi sayısı her geçen yll artan bir destinasyondur. Literatüre dayall oluşturulan anket aracılığıyla bir alan araştırması yapılmış ve Amasya'yı hiç ziyaret etmemiş 807 kişiye anket uygulanmıştır. Çalışma sonucunda katılımcıların Amasya'nın yeterince tanıtıldığını düşünmedikleri ve Amasya hakkında yeterli bilgiye sahip olmadıkları için ziyaret etmedikleri tespit edilmiştir. Elde edilen sonuçlardan ve sunulan önerilerden Amasya destinasyonundaki turizm paydaşlarının faydalanacă̆ öngörülmektedir.
\end{abstract}

\section{ANAHTAR KELIMELER}

Destinasyon, Imaj, Amasya, Turizm

\begin{abstract}
Image is very important for the marketing success of a destination. Among the reasons for visiting a destination, the positive image of that destination can be counted as well as the reason for not visiting may be the negative image in the eyes of potential visitors. In this study, it is aimed to learn the destination images of those who have never visited Amasya before and why they did not visit. Amasya is a destination with an important history and cultural background, high tourism potential and an increasing number of visitors every year. A survey was conducted through a questionnaire based on the literature and a questionnaire was conducted to 807 participants who have never visited Amasya. As a result of the study, it was determined that the participants think that Amasya was inadequately promoted and they did not visit because they did not have enough information about Amasya. It is predicted that the tourism stakeholders in Amasya destination will benefit from the results obtained and the suggestions provided.
\end{abstract}

\section{KEYWORDS}

Destination ,Image, Amasya, Tourism

\begin{tabular}{|c|c|c|}
\hline \multicolumn{2}{|r|}{$\begin{array}{l}\text { Makale Geliş Tarihi / Submission Date } \\
06.02 .2020\end{array}$} & $\begin{array}{c}\text { Makale Kabul Tarihi / Date of Acceptance } \\
27.05 .2020\end{array}$ \\
\hline Atıf & $\begin{array}{l}\text { Ery1lmaz, B. (2020). Ziyaret Etmeyen } \\
\text { Sosval Bilimler Meslek Yüksekokulu D. }\end{array}$ & Bir Destinasyon Olarak Amasya. Selçuk Üniversitesi \\
\hline
\end{tabular}

\footnotetext{
* Dr.Öğr.Üyesi, Amasya Üniversitesi, Sosyal Bilimler MYO, burak.eryilmaz@ amasya.edu.tr, ORCID: 0000-0002-2179-5450
} 


\section{GİRIŞ}

Turistlerin seyahate çıkmaya karar verdikten sonra belki de vermeleri gereken en önemli karar seyahat edecekleri destinasyonu belirlemektir. Seçilen destinasyon; seyahat tarihlerini, talep edilen turizm şeklini, ulaşım alternatiflerini, konaklama seçeneklerini de etkilemektedir. Çeşitli kriterlere göre yapılan destinasyon seçimlerinde, destinasyonun turist gözündeki imajı ise oldukça önemlidir.

Bir veya birden fazla insanın bir yer ile ilgili algısı olarak tanımlanan destinasyon imajı; insanların destinasyonla ilgili inanç, görüş ve izlenimlerinin toplamından oluşmaktadır (Hosany vd, 2006). Bir destinasyonun turistler tarafından tercih edilmesi ile destinasyon imajı arasındaki ilişki oldukça kuvvetlidir. $\mathrm{Bu}$ yüzden destinasyon imajının öğrenilmesi destinasyonun geliştirilmesi için oldukça önemlidir (Yamaç ve Zengin, 2015).

İmaj konusunda yapılan birçok çalışmada turistlerin ziyaret ettikleri veya bildikleri destinasyonlarla ilgili algıları ölçülmeye çalışılmıştır. Bu çalışma, ziyaret etmeyenlerin görüşlerinin alınması açısından önemli görülmektedir. Çalışmada Amasya'yı daha önce hiç ziyaret etmeyenlerin Amasya ile ilgili düşünceleri öğrenilerek, insanların daha önce hiç gitmedikleri bir yeri zihinlerinde nasıl canlandırdıkları ile ilgili fikir edinilmesi amaçlanmıştır. Çalışma alanı olarak Amasya'nın seçilme sebepleri arasında; Kültür ve Turizm Bakanlığı tarafından özellikle kültür turizminin geliştirilmesi için seçilen marka kentlerden birisi olması, zengin bir tarihi geçmişe sahip olması ve ziyaretçi sayısının artırılması için yapılan çalışmaların son yıllarda artmas1 gösterilebilir.

Amasya 7500 yıllık tarihi ile Kral Kaya Mezarları, Yalıboyu Evleri, Harşena Kalesi, camileri, hanları, hamamları ile zengin bir turizm potansiyeline sahip bir destinasyondur. Antik çağlara dayanan uzun geçmiş, Amasya'da izlerini bırakmış ve kültürel miras olarak günümüze kadar gelmiştir. Kültür ve Turizm Bakanlığı Türkiye Turizm Stratejisi Eylem Planı (2007-2013) içerisinde yer alan 'Kentsel Ölçekte Markalaşma Stratejisi' kapsamında kültürel ve doğal değerlere sahip kentlerimizin markalaştırılarak, yerli ve yabancı turistler için çekim noktası haline getirilmesi amaçlanmaktadır. Bu kapsamda, kültürel ve tarihi geçmiş kıstas alınarak Kültür Turizmi Geliştirilecek 15 Marka Kent seçilmiş ve Amasya da seçilen bu kentlerden birisi olmuştur (www.oka.org.tr) .

Bu çalışmada Amasya'nın algılanan imajı, bu destinasyona daha önce hiç gitmemiş kişilerin gözüyle değerlendirilmeye çalışılmıştır. Amasya destinasyonuna yönelik imaj çalışmalarında özellikle daha önce Amasya'yı hiç ziyaret etmemiş kişilerin düşüncelerinin saptanmasının Amasya açısından oldukça önemli olduğu düşünülmektedir. Elde edilecek sonuçlara göre ziyaret etmeyenlerin zihinlerindeki düşünceler öğrenilebilir ve olumlu olanlar pekiştirilirken olumsuz olanlar da ortadan kaldırılabilir ise şehrin turistik açıdan pazarlanmasına ve gelişmesine katkıda bulunulabilir.

\section{LITERATÜR TARAMASI}

Destinasyonların imajları ile ilgili literatürde birçok çalışma yer almaktadır. Destinasyon ile ilgili imajın seyahat tercihlerine etkileri (Gallarza vd., 2002), turistlerin memnuniyet dereceleri üzerindeki etkileri (O’Leary ve Deegan, 2005), destinasyonlara olan bağlllık seviyelerine etkisi (SanMartin ve Del Bosque, 2008) gibi konular üzerinde yapılan ulusal ve uluslararası birçok çalışma bulunmaktadır.

Assaker vd. (2011: 892), destinasyon imajının turistlerin davranışsal niyetlerini etkilediğini belirtmişlerdir. Buna göre destinasyonu ziyaret eden bir turistin, imaj algısı olumlu ise destinasyonu tekrar ziyaret etmeyi isteyebileceği, imaj algısı olumsuz olan bir turistin ise destinasyonu tekrar ziyaret etme niyetinin olmayacağ 1 sonucu çıkarılabilir. Ketter (2016: 67) tarafından destinasyon imajının turistlerin davranışlarının öngörülmesinde kritik bir faktör olarak yer aldığ 1 ve olumlu bir destinasyon imajının turistleri destinasyona çekme açısından rekabet avantajı sağladığı belirtilmektedir. Destinasyon imaj1 ve turist sadakati arasındaki ilişkiyi inceleyen Zhang vd. (2014), destinasyon imajının turist sadakati üzerinde önemli etkileri olduğu sonucuna ulaşmıştır.

Destinasyon imaj1, turistlerin destinasyon seçimlerini anlamada önemli bir faktördür (Choi vd., 2011). Potansiyel turistlerin destinasyonla ilgili imaj algıları, o destinasyonun başarısını ve geleceğini belirlemektedir. Özellikle destinasyonlar arası rekabette olumlu imaja sahip olanlar kendilerine avantaj sağlamaktadırlar (Kavacık vd., 2012). Bu yüzden destinasyonların tanıtım politikalarını belirlemeden önce potansiyel turistler gözündeki imajın öğrenilmesi avantaj sağlayacaktır. İmaj doğru tespit edildiğinde, turistlerin karar alma süreçlerinde turistleri etkileyebilmek daha kolay olacaktır. Bir diğer ifadeyle destinasyonların turistik açıdan pazarlanabilmeleri için turistlerin gözündeki algılarının ölçülmesi ve bu imaj doğrultusunda tanıtım ve pazarlama stratejilerinin geliştirilmesi gerekmektedir (Ceylan,2011).

Destinasyon imajının araştırmacılar tarafından farklı tanımları yapılmıştır. Örneğin Kotler (1994) destinasyon imajını; "kişinin bir destinasyon hakkında sahip olduğu inanışların, fikirlerin, duyguların, 
beklentilerin ve izlenimlerin sonucudur" şeklinde tanımlamıştır. Gallarze vd (2002) ise imajı; turistlerin yörede yaşayan yerel halk, işletmeler ve çalışanlar hakkındaki izlenimlerinin bir bütünü olarak tanımlamışlardır (Yaraşl1, 2007). Hosany vd (2006); destinasyon imajının bir veya birden fazla insanın bir yer ile ilgili algısı olarak tanımlanabileceğini ve bu algının bir kişinin o yerle ilgili inanç, görüş ve izlenimlerinin toplamından oluştuğunu belirtmişlerdir (Şahin ve Baloğlu, 2011).

Gunn (1988), destinasyon imajını 2 kavramla ele almıştır. Bunlardan birisi organik imaj, diğeri ise uyarılmış imajdır. Organik imaj; turistik ve ticari olmayan kaynaklardan elde edilen, tv, radyo, gazete, dergi gibi yazılı ve görsel medya araçları, eğitim, arkadaş ve aile görüşlerinden oluşan gerçek ziyaretçilerden elde edilen bilgilerle oluşan imajdır. Uyarılmış imaj ise organik imajı değiştirme etkisi olan, müşterilerin ticari bilgi kaynaklarını kullanarak geliştirdikleri ve ortaya çıkan imajdır (Murphy, 2000).

Kotler vd (1993) bir destinasyonun turistler gözündeki imajının 4 farklı şekilde olabileceğini belirtmişlerdir. Bunlar; olumlu ve etkileyici, zayıf (çok iyi bilinmeyen destinasyonlar), karışık (imaj hem olumlu hem olumsuz bileşenlerden oluşabilir) veya çelişkili (destinasyonun belirli bir grup üzerinde imaj1 olumluyken başka bir topluluk üzerinde olumsuz olması) olmasıdır (Kim ve Lee, 2015).

Bir destinasyonu ziyaret edenler için imaja olumlu veya olumsuz etki edecek birçok unsur bulunmaktadır. Bölgede edinilen deneyimler, konaklama yapılan işletmeler, alınan ürün ve hizmetler, ulaşım ihtiyaçlarının giderilme durumu, yerel halkın ve turizm çalışanlarının tutumları, fiyatlar, eğlence olanakları, yeme içme hizmetleri bunlardan öne çıanlardır (Akyurt ve Atay, 2009).

İmajın bir destinasyonun başarısındaki rolü büyüktür. Başarıdan kast edilen destinasyonun turistler tarafindan tercih edilme durumudur. Sahip olunan olumlu imaj, potansiyel ziyaretçilerin seçim süreçlerini etkilerken; memnuniyet, tekrar gelme isteği ve başkalarına tavsiye gibi ziyaret sonrası davranışlarını da etkilemektedir (Song ve Hsu, 2013). Bir destinasyonla ilgili olumlu imaj, potansiyel turisti destinasyonu tercih etmeye yöneltirken, olumsuz imaj ise karar verme aşamasındaki turistin tercihinden vazgeçmesine neden olabilmektedir. Turistik hizmetlerin soyut olması zihinsel canlandırmaları önemli kılmakta dolayısıyla zihinsel olgu olan imajın önemi daha da artmaktadır (Pekyaman, 2008). Olumsuz bir imajı olumluya çevirmek ise oldukça zordur. Bu yüzden bir destinasyon için imaj eksikliğinin, imajın kötü olmasından daha iyi bir durum olduğu kabul edilebilir (Üner vd, 2006).

Destinasyon imajı sabit veya kalıcı da değildir. İmaj zaman içerisinde değişen turist tutum ve davranışlarına veya destinasyon çevresindeki bir takım değişikliklere göre farklılaşabilir. Seyahat öncesi ve seyahat sonrasında imajda farklılıklar ortaya çıkabildiği gibi bir destinasyona ilk kez seyahat edecek turistlerin imaj algıları ile daha önce gidenlerin algıları arasında farlılıkların olması da muhtemeldir. Turistlerin destinasyonla ilgili bilgileri ve motivasyonları da farklı olacaktır. Daha önce seyahat edenler ilk zaman öğrendikleri bilgileri hatırlama eğiliminde olurken hiç ziyaret etmeyenler ise zihinlerinde farklı kaynaklardan edindikleri bilgiler ile oluşan beklentilerine cevap arayacaklardır.

Bir destinasyonu daha önce hiç ziyaret etmeyenlerin kimler olduğunu iyi anlamak gerekmektedir. Bu kişiler bir destinasyonu ileriki bir zaman diliminde ziyaret etme ihtimalleri olan, çeşitli sebeplerden dolayı şimdiye kadar ziyaret etmemiş veya herhangi bir sebepten dolayı ziyaret etmeyi tercih etmeyenlerden oluşmaktadır. Bir destinasyonu daha önce ziyaret etmeyen bir turistin aklında destinasyonun sağladığı zihinsel manzara veya deneyimle oluşan imaj oluşmaz. Bu kişilerde ancak destinasyonla ilgili reklam veya duyumlarla bir imaj belirebilir.

Sussman ve Urel (1999); destinasyon pazarlamacılarının müşteri memnuniyeti sağlayabilmek için seyahat öncesi destinasyon imajı ile seyahat sonrası destinasyon imajı arasındaki ilişkiyi iyi anlamaları gerektiğini belirtmişlerdir. Jaxi ve Hwang (2011) ziyaret öncesi ve ziyaret sonrası destinasyon imajını karşılaştırdıkları çalışmalarında Zanzbar Adası'nı ziyaret edenlerin adayla ilgili henüz ziyaret etmemiş ancak ziyaret etmeyi düşünenlere göre daha olumlu imaja sahip oldukları sonucuna ulaşmışlardır.

Choi vd. (2011) yaptıkları çalışmada Kore'nin algılanan imajında ziyaretçiler ve ziyaret etmeyenler arasında farklılık olduğunu belirtmişlerdir. Turistlerin destinasyonla ilgili bilgileri ve motivasyonları da farklı olacaktır. Daha önce seyahat edenler ilk zaman öğrendikleri bilgileri hatırlama eğiliminde olurken hiç ziyaret etmeyenler ise zihinlerinde farklı kaynaklardan edindikleri bilgiler ile oluşan beklentilerine cevap arayacaklardır.

Destinasyonların potansiyel ziyaretçileri etkileyecek imaja sahip olmaları oldukça önemlidir. Özellikle birbirleriyle rekabet halinde olan destinasyonların rakipleriyle olan farklılıklarını ön plana çıkartması gerekmektedir (Şahin ve Baloğlu, 2011).Bunun için de turistlerin zihinlerindeki imajın doğru bir şekilde tespit edilmesi gerekmektedir.

Cherif vd.(2014) yaptıkları çalışmada kişilerin daha önce ziyaret etmedikleri destinasyonlarla ilgili zihinlerinde imajın belirmesinde daha önce ziyaret ettikleri yerlerle yaptıkları karşılaştırmaların etkisinden 
bahsetmişlerdir. Ayrıca çalışmada ikincil yani başkalarından öğrenilen deneyimlerin imaj oluşumuna etki ettiği vurgulanmıştır.

Demirel (2014) yaptığı çalışmada güçlü bir destinasyon imajının destinasyonların her açıdan gelişmelerine, kalkınmalarına katkı sağlayacak destekleyici bir unsur olarak görülmesi gerektiğini belirtmiştir.

Fırat ve Kömürcüoğlu (2015) destinasyon imajının insanların zihinlerinde oluşturdukları inançlar, fikirler ve izlenimlerin bütünü olduğunu, farklı kaynaklardan elde edilen bilgi, deneyim ve gözlemlerin bigilerle birleştiğinde imajın ortaya çıktığını belirtmişlerdir.

Bir destinasyonun ziyaret edilmeme sebebi destinasyonun bozuk veya eksik imajından kaynaklanabilir. Bu yüzden bu çalışmanın da amacında olduğu gibi hiç ziyaret etmeyenlerin destinasyon imajlarını öğrenmeye odaklanmak faydalı olacaktır.

\section{2. ÇALIŞMANIN KAPSAMI VE YÖNTEM}

$\mathrm{Bu}$ çalışma, bir nicel araştırmadır. Betimsel tarama modeli takip edilerek yürütülmüştür. Betimsel tarama modeli, geniş bir popülasyona ait düşünceleri, eğilimleri ve tutumları ortaya koymayı amaçlayan bir nicel araştırma modelidir (Creswell, 2012).

Araştırma problemlerini yanıtlamak için araştırmacı tarafından bir anket geliştirilmiştir. Geliştirilen anket; katılımcıların demografik bilgilerini, turizm açısından Amasya'ya ilişkin algılarını, turizme ve Amasya'ya ilişkin görüşlerini elde etmeyi amaçlayan sorulardan oluşmaktadır. Anket maddeleri oluşturulurken kapsam geçerliliği açısından uzman görüşüne sunulmuştur. Madde havuzundan oluşturulan uzman görüşü alma formu turizm işletmeciliği alanında uzman akademisyenlerin incelemesine sunulmuştur. Uzmanların incelemesine sunulan maddelerden sorunlu, yetersiz, anlaşılması zor veya kapsam dışı olarak değerlendirilenler anketten çıkartılmış, eleştirilen maddeler ise düzeltilerek ankete son hali verilmiştir.

Anketin amacı, katılımcıların tarihi ve turistik zenginliklerini ön plana çıkararak yeni bir destinasyon olma yönünde ilerleyen Amasya'nın mevcut imajına ilişkin görüşlerini belirlemektir. Araştırma evrenini Amasya'yı şimdiye kadar hiç ziyaret etmemiş bireyler oluşturmaktadır. Ancak tüm bireylere ulaşılması mümkün olmadığından örnekleme yapılması zorunlu görülmüştür. Katılımcılar kolayda örnekleme yöntemiyle belirlenmiştir. Bu yöntem doğrultusunda hedef örneklem grubuna ulaşmak için kolay ulaşılabilir durumda olan bireyler çalışmaya dahil edilmiştir. Örneklemin ana kütleyi iyi temsil etmesi gerektiği göz önünde bulundurularak mümkün olduğunca farklı sosyo-kültürel ve ekonomik özellikleri olan bireylere ulaşılmaya çalışılmıştır.

Toplam 1000 adet anket dağıtılmış ve bu anketlerden 844 adet geri dönüş alınmıştır. Hatalar içeren 37 anketin değerlendirme dişı tutulması sonucunda toplam 807 adet anket veri girişi için uygun görülmüştür. Anketler başta İstanbul, Ankara, Sakarya, Bolu gibi illerde çalışmaya yardımcı olmaya gönüllü kişiler tarafindan yüz yüze görüşme yöntemiyle uygulanmıştır. Bununla birlikte daha fazla kişiye ulaşabilmek için anket formu "surveymonkey.com" web sitesi kullanılarak elektronik ortama taşınmış ve sosyal medya araçlarıyla duyurusu yapılarak katılım sağlanmıştır.

Anketlerden elde edilen verilerin analizinde ölçeklerden elde edilen verilerin analizinden farklı bir yaklaşımın takip edilmesi önerilmektedir. Boone ve Boone'ye (2012) göre, anket maddelerine verilen yanıtlar ordinal veri olarak kabul edilmektedir ve ilgili veriler üzerinde fark testleri yapilırken parametrik olmayan testlerin kullanılması önerilmektedir. Dolayısıyla bu çalışmada fark testleri yapılırken Mann-Whitney U testi ve Kruskal-Wallis testi kullanılmıştır.

Uygulanan anketin güvenilirliği Cronbach Alpha katsayısı ile kontrol edilmiştir. Katılımcıların turizme ilişkin görüşlerini belirlemek için belirlenen maddelere ilişkin Cronbach Alpha katsayısı 0.82, Amasya'ya ilişkin düşüncelerinin belirlenmesi için yer alan maddelere ilişkin ise 0.73 olarak belirlenmiştir. Elde edilen bu güvenilirlik katsayıları anketin güvenilir olduğunu göstermektedir.

Bu çalışma Amasya'nın imajını öğrenmeye yönelik öncül bir çalışma olmakla birlikte bazı sınırlılıklara da sahiptir. Çalışma örnekleminin sınırlı kalması en önemli sınırlılık olarak görülmektedir. Ayrıca anketi katılımcılara uygulayacak gönüllülerin sadece İstanbul, Ankara, Sakarya ve Bolu illerinde bulunmaları dolayısıyla bu illerde anketlerin yüz yüze uygulanması diğer illerde ise internet aracıllğıyla veri toplanmaya çalışılması bir diğer sınırlılıktır.

\section{BULGULAR}

Araştırma problemlerini yanıtlamak için gerçekleştirilen analizler sonucunda elde edilen bulgular alt başlıklar halinde verilmiştir. 


\subsection{Katılımcilar}

Çalışmaya farklı demografik özelliklere sahip toplam 807 birey katılmıştır. Kolayda örnekleme yöntemi kullanılarak katılımcılara ulaşılmıştır. Katılımcılar gönüllülük esasına dayalı olarak çalışmaya dahil olmuştur. Katılımcıların demografik özelliklerine ait veriler, Tablo 1'de sunulmuştur.

Tablo 1 incelendiğinde, katılımcıların cinsiyet ve medeni durum açısından dengeli bir dağılıma sahip olduğu görülmektedir. Bununla birlikte katılımcıların çoğunluğunun 21-50 yaş grubu arasında olduğu, üniversite düzeyine öğrenim gördüğü ve 3000 TL üstünde gelire sahip olduğu belirlenmiştir.

Tablo 1: Katılımcılara Ait Demografik Bilgiler

\begin{tabular}{|l|l|c|c|}
\hline \multicolumn{1}{|c|}{ Kategori } & \multicolumn{1}{|c|}{ Alt Kategori } & Frekans (f) & Yüzde (\%) \\
\hline \multirow{3}{*}{ Cinsiyet } & Kadın & 367 & 45,5 \\
\cline { 2 - 4 } & Erkek & 440 & 54,5 \\
\hline \multirow{5}{*}{ Medeni Durum } & Evli & 353 & 43,7 \\
\cline { 2 - 4 } & Bekar & 454 & 56,3 \\
\hline \multirow{5}{*}{ Yaş } & 20 yaş ve altı & 24 & 3,0 \\
\cline { 2 - 4 } & $21-35$ yaş & 300 & 37,2 \\
\cline { 2 - 4 } & $26-50$ yaş & 171 & 21,2 \\
\cline { 2 - 4 } & $51-65$ yaş & 217 & 26,9 \\
\cline { 2 - 4 } & 66 yaş ve üstü & 95 & 11,8 \\
\hline \multirow{5}{*}{ Gelitim (Aylık-TL) } & İlköğretim & 43 & 5,3 \\
\cline { 2 - 4 } & Lise & 160 & 19,8 \\
\cline { 2 - 4 } & Üniversite (2 Y1ll1k) & 152 & 18,8 \\
\cline { 2 - 4 } & Üniversite (4 Y1l1k) & 387 & 48,0 \\
\cline { 2 - 4 } & Lisansüstü & 65 & 13,1 \\
\hline & $0-1500$ & 112 & 25,4 \\
\cline { 2 - 4 } & $1501-3000$ & 205 & 23,9 \\
\cline { 2 - 4 } & $3001-5000$ & 193 & 18,8 \\
\cline { 2 - 4 } & $5001-7000$ & 101 & 5,5 \\
\cline { 2 - 4 } & $7001-10000$ & 44 & \\
\cline { 2 - 4 } & 10001 ve üstü & & 12,5 \\
\hline
\end{tabular}

\subsection{Amasya ile Özdeşleştirilen Unsurlar}

Katılımcılara yöneltilen “Amasya denilince aklınıza gelen ilk üç şey nedir?” sorusuna verdikleri yanıtlara ilişkin dağılım, Tablo 2'de sunulmuştur.

Tablo 2 incelendiğinde, katılımcıların çoğunluğunun Amasya denilince akla gelen şeyler sorulduğunda birinci tercih olarak "Amasya Elması" nı göstermeleri dikkat çekicidir. Bununla birlikte "Mumyalar" ve "Evliyalar Şehri" unsurları, katılımcılar tarafından Amasya denilince akla gelen şeyler arasında en düşük düzeyde belirtilmektedir.

Tablo 2: Amasya Denilince Akla Gelen Unsurlara İlişkin Bulgular

\begin{tabular}{|l|c|c|c|c|c|c|}
\hline \multirow{2}{*}{ Unsurlar } & \multicolumn{2}{c|}{$\begin{array}{c}\text { Birinci } \\
\text { Tercih }\end{array}$} & \multicolumn{2}{c|}{$\begin{array}{c}\text { Ikinci } \\
\text { Tercih }\end{array}$} & \multicolumn{2}{c|}{$\begin{array}{c}\text { Üçüncü } \\
\text { Tercih }\end{array}$} \\
\cline { 2 - 7 } & f & \% & f & \% & f & $\%$ \\
\hline Amasya Çöreği & 29 & 3,6 & 44 & 5,5 & 41 & 5,1 \\
\hline Yeşilırmak & 20 & 2,5 & 72 & 8,9 & 159 & 19,7 \\
\hline Özçekim Yapan Şehzade & 12 & 1,5 & 35 & 4,3 & 39 & 4,8 \\
\hline Amasya Genelgesi & 127 & 15,7 & 238 & 29,5 & 119 & 14,7 \\
\hline SSehzadeler & 68 & 8,4 & 98 & 12,1 & 117 & 14,5 \\
\hline Ferhat ile Şirin & 43 & 5,3 & 114 & 14,1 & 83 & 10,3 \\
\hline Amasya Elması & 481 & 59,6 & 133 & 16,5 & 111 & 13,8 \\
\hline Mumyalar & 8 & 1,0 & 4 & 0,5 & 6 & 0,7 \\
\hline Kral Kaya Mezarlar1 & 10 & 1,2 & 29 & 3,6 & 72 & 8,9 \\
\hline Evliyalar Şehri & 9 & 1,1 & 40 & 5,0 & 60 & 7,4 \\
\hline
\end{tabular}




\subsection{Amasya'yı Ziyaret Etmeme Sebeplerine İlişkin Görüşleri}

Katılımcıların Amasya'yı şimdiye kadar ziyaret etmeme sebeplerine ilişkin sorulan soruya verdikleri yanıtlara ilişkin bulgular Tablo 3'de sunulmuştur.

Tablo 3 incelendiğinde, katılımcıların Amasya'yı ziyaret etmemelerine ilişkin en güçlü sebep olarak "Amasya hakkında yeterli bir bilgiye sahip değilim" maddesi olduğu $(\mathrm{X}=4,18)$, en zayıf sebebin ise “Amasya ya yapacağım seyahat bana prestij katmaz" maddesi olduğu $(\mathrm{X}=2,65)$ belirlenmiştir.

Tablo 3: Amasya'yı Ziyaret Etmeme Sebeplerine İlişsin Bulgular

\begin{tabular}{|l|c|c|c|}
\hline \multicolumn{1}{|c|}{ Maddeler } & N & Ortalama & Standart Sapma \\
\hline Ulaşımı kolay değil. & 807 & 3,25 & 1,238 \\
\hline Turistik bir destinasyon olduğunu düşünmüyorum. & 807 & 3,16 & 1,356 \\
\hline Amasya hakkında yeterli bir bilgiye sahip değilim. & 807 & 4,18 & 1,100 \\
\hline Benim için ilgi çekici bir destinasyon değil. & 807 & 3,24 & 1,413 \\
\hline Popüler bir destinasyon değil. & 807 & 3,62 & 1,297 \\
\hline Amasya'ya yapacağım seyahat bana prestij katmaz. & 807 & 2,65 & 1,436 \\
\hline
\end{tabular}

\subsection{Son Bir Yıl İçerisinde Amasya ile İlgili Tanıtım Materyaline Rastlama Durumları}

Katılımcıların son bir yıl içerisinde Amasya ile ilgili herhangi bir tanıtım materyaline rastlayıp rastlamadıklarına, rastladılar ise bilgi kaynaklarının ne olduğunu öğrenmeye ilişkin sorulara verdikleri yanıtların analiz edilmesiyle elde edilen bulgular Tablo 4'de sunulmuştur.

\section{Tablo 4: Son Bir Yıl İçerisinde Amasya ile ilgili Tanıtım Materyaline Rastlanmasına İliş̧kin Bulgular}

\begin{tabular}{|c|c|c|c|}
\hline Maddeler & & Frekans & Yüzde (\%) \\
\hline \multirow{2}{*}{$\begin{array}{c}\text { Son 1 yıl içerisinde Amasya ile ilgili herhangi bir } \\
\text { tanıtım materyaline rastladınız mı? }\end{array}$} & Evet & 108 & 13,4 \\
\cline { 2 - 4 } & Hayır & 699 & 86,6 \\
\hline \multirow{3}{*}{ Cevap Evet İse Bilgi Kaynağ } & Sosyal Medya & 40 & 5,0 \\
\cline { 2 - 4 } & Gazete & 10 & 1,2 \\
\cline { 2 - 4 } & İnternet & 39 & 4,8 \\
\cline { 2 - 4 } & TV & 15 & 1,9 \\
\cline { 2 - 4 } & Fuar & 4 & 0,5 \\
\hline
\end{tabular}

Elde edilen ilgili bulgular incelendiğinde, katılımcıların \%86,6 gibi büyük bir çoğunluğunun son 1 yıl içerisinde Amasya ile ilgili bir tanıtım materyaline rastlamadıkları belirlenmiştir. Tanıtım materyaline rastlayan \% 13,4'lük kısmın ise en önemli bilgi kaynaklarının sosyal medya ve internet olduğu tespit edilmiştir.

\subsection{Tatilden Öncelikli Beklentilere İlişkin Görüşler}

Katılımcıların tatilden öncelikli beklentilerine ilişkin görüşlerini yansıtan betimsel istatistik değerleri Tablo 5 'te sunulmuştur.

Tablo 5: Tatilden Öncelikli Beklentilere İlişkin Bulgular

\begin{tabular}{|l|c|c|c|}
\hline \multicolumn{1}{|c|}{ Maddeler } & N & Frekans & Yüzde (\%) \\
\hline Yakın Çevreden Uzaklaşmak & 807 & 109 & 13,5 \\
\hline Şehir stresinden Kurtulmak & 807 & 93 & 11,5 \\
\hline Yeni yerler keşfetmek & 807 & 409 & 50,7 \\
\hline Yeni lezzetler tatmak & 807 & 9 & 1,1 \\
\hline Alişveriş yapmak & 807 & 4 & 0,5 \\
\hline Yeni insanlar tanımak & 807 & 49 & 6,1 \\
\hline Sadece dinlemek & 807 & 134 & 16,6 \\
\hline
\end{tabular}

Tablo 5 incelendiğinde, katılımcıların çoğunluğunun yeni yerler keşfetme isteğini tatilden öncelikli beklentileri arasında gösterdiği görülmektedir. Bununla birlikte alışveriş yapmak ve yeni lezzetler tatmak en düşük düzeyde belirtilen tatilden öncelikli beklentiler olarak göze çarpmaktadır. 


\subsection{Amasya'nın Ziyaret Edilmeme Sebepleri ile Tatilden Öncelikli Beklentileri Arasındaki İlişki}

Katılımcıların Amasya'yı ziyaret etmeme sebepleri ile tatilden öncelikli beklentileri arasındaki ilişkiyi incelemek amacıyla parametrik olmayan Kruskal-Wallis testi yapılmıştır. Test sonuçları Tablo 6'da sunulmuştur.

Tablo 6: Amasya'yı Ziyaret Etmeme Sebepleri ile Tatilden Öncelikli Beklentiler Arasındaki İlişki

\begin{tabular}{|l|c|c|c|c|}
\hline \multicolumn{1}{|c|}{ Maddeler } & N & $\begin{array}{c}\text { Ki-Kare } \\
\text { Değeri }\end{array}$ & $\begin{array}{c}\text { Serbestlik } \\
\text { Derecesi }\end{array}$ & p \\
\hline Ulaşımı kolay değil. & 807 & 35,520 & & 0,000 \\
\hline Turistik bir destinasyon olduğunu düşünmüyorum. & 807 & 6,732 \\
\cline { 1 - 2 } Amasya hakkında yeterli bir bilgiye sahip değilim. & 807 & 31,181 & \multirow{4}{*}{6} & 0,346 \\
\cline { 1 - 3 } Benim için ilgi çekici bir destinasyon değil. & 807 & 18,067 & 0,000 \\
\hline Popüler bir destinasyon değil. & 807 & 23,655 & & 0,006 \\
\hline Amasya'ya yapacağım seyahat bana prestij katmaz. & 807 & 12,319 & & 0,001 \\
\cline { 1 - 2 }
\end{tabular}

Tablo 6 incelendiğinde; "ulaşımı kolay değil" (Ki-Kare=35.520, p<.001), "Amasya hakkinda yeterli bir bilgiye sahip değilim" (Ki-Kare=31.181, p<.001), "Benim için ilgi çekici bir destinasyon değil" (KiKare $=18.067, \mathrm{p}<.01)$ ve "Popüler bir destinasyon değil" (Ki-Kare=23.655, p<.01) sebeplerinin kat1lımcıların tatilden öncelikli beklentilerine göre anlamlı farklılık gösterdiği belirlenmiştir.

\subsection{Amasya'nın Ziyaret Edilmeme Sebepleri ile Karşılaştıkları Tanıtım Materyali İle Karşılaşma} Durumu Arasındaki İlişki

Katılımcıların Amasya'yı ziyaret etmeme sebepleri ile Amasya ile ilgili tanıtım materyalleri ile karşılaşma durumları arasındaki ilişkiyi incelemek amacıyla parametrik olmayan Kruskal-Wallis testi yapılmıştır. Test sonuçları Tablo 7'de sunulmuştur.

\section{Tablo 7: Amasya'yı Ziyaret Etmeme Sebepleri ile Tanıtım Materyalleri ile Karşılaşma Durumları} Arasındaki İlişkiye İliş̧in Bulgular

\begin{tabular}{|l|c|c|c|c|}
\hline \multicolumn{1}{|c|}{ Maddeler } & N & $\begin{array}{c}\text { Ki-Kare } \\
\text { Değeri }\end{array}$ & $\begin{array}{c}\text { Serbestlik } \\
\text { Derecesi }\end{array}$ & p \\
\hline Ulaşımı kolay değil. & 109 & 8,406 & & 0,078 \\
\hline Turistik bir destinasyon olduğunu düşünmüyorum. & 109 & 5,558 & & 0,235 \\
\hline Amasya hakkında yeterli bir bilgiye sahip değilim. & 109 & 2,027 & \multirow{4}{*}{4} & 0,731 \\
\hline Benim için ilgi çekici bir destinasyon değil. & 109 & 8,076 & & 0,089 \\
\hline Popüler bir destinasyon değil. & 109 & 15,385 & & 0,004 \\
\hline Amasya'ya yapacağım seyahat bana prestij katmaz. & 109 & 6,615 & & 0,158 \\
\hline
\end{tabular}

Tablo 7 incelendiğinde, "Popüler bir destinasyon değil" (Ki-Kare=15.385, p<.01) sebeplerinin katılımcıların tanıtım materyalleri ile karşılaşma durumlarına göre anlamlı farklılık gösterdiği belirlenmiştir. Diğer sebepler bağlamında anlamlı farklılığa ulaşılmamıştır.

\subsection{Cinsiyete Göre Katılımcıların Turizme ve Amasya'ya İlişkin Görüşleri}

Katılımcıların cinsiyetlerine göre turizme ilişkin görüşlerinin farklılaşıp farklılaşmadığını belirlemek için Mann-Whitney U testi yapılmıştır. İlgili analiz sonuçları Tablo 8'de verilmiştir.

Tablo 8 incelendiğinde, "Tatil yeri belirlerken daha önce gitmediğim yerlere öncelik veririm" $(\mathrm{z}=-3.307$, $\mathrm{p}<.01)$, "Tatile gittiğimde kisa süreli konaklamalarla farklı yerler görmeyi severim" $(\mathrm{z}=-1,974, \mathrm{p}<.05)$, "Tatilden dönüşte hem kendime hem de yakınlarıma mutlaka hatıra eşyası satın alırım" $(\mathrm{z}=-4,017, \mathrm{p}<.01)$ ve "Tatil yaptı̆̆ım yerde sosyal medya aracılı̆̆ ile paylaşımda bulunurum" ( $\mathrm{z}=-4,965, \mathrm{p}<.01)$ maddeleri için kadınların lehine istatistiksel açıdan anlamlı farklılık olduğu belirlenmiştir. "Bağımlı (turlara katılarak rehber eşliğinde) seyahat etmeyi severim" maddesi için ise erkekler lehine istatistiksel açıdan anlamlı farklılık olduğu görülmektedir $(\mathrm{z}=-2,429, \mathrm{p}<.05)$.

Ayrıca tabloda yer alan maddelere verilen cevapların ortalamaları incelendiğinde en yüksek ortalamanın "Tatil için seçeceğim yer ile ilgili Tv, gazete, sosyal medya vb. ortamlarda yapılan tanitımlar üzerimde olumlu bir izlenim bırakır" ve "Tatil yeri seçerken mutlaka internette düşündüğüm yer ile ilgili araştırma yaparım" maddelerinde olduğu görülmektedir. 
Tablo 8: Turizme İlişkin Görüşlerin Cinsiyete Göre Değişimi

\begin{tabular}{|c|c|c|c|c|c|c|c|c|}
\hline Maddeler & Cinsiyet & $\mathbf{N}$ & Ortalama & $\begin{array}{c}\text { Sira } \\
\text { Ortalaması }\end{array}$ & $\begin{array}{c}\text { Sira } \\
\text { Toplamı }\end{array}$ & $\mathbf{U}$ & $\mathbf{Z}$ & $\mathbf{p}$ \\
\hline \multirow{2}{*}{$\begin{array}{l}\text { Tatil için seçeceğim yer ile ilgili Tv, } \\
\text { gazete, sosyal medya vb. ortamlarda } \\
\text { yapılan tanıtımlar üzerimde olumlu } \\
\text { bir izlenim bırakır. }\end{array}$} & Kadın & 367 & 4,55 & 405,26 & 148803 & \multirow{2}{*}{80205} & \multirow{2}{*}{$-0,19$} & \multirow{2}{*}{0,85} \\
\hline & Erkek & 440 & 4,51 & 402,78 & 177225 & & & \\
\hline \multirow{2}{*}{$\begin{array}{l}\text { Tatil yeri belirlerken daha önce } \\
\text { gitmediğim yerlere öncelik veririm. }\end{array}$} & Kadın & 367 & 4,46 & 430,71 & 158071 & \multirow{2}{*}{70937} & \multirow{2}{*}{$-3,307$} & \multirow{2}{*}{0,001} \\
\hline & Erkek & 440 & 4,26 & 381,72 & 167957 & & & \\
\hline \multirow{2}{*}{$\begin{array}{l}\text { Bağımlı (turlara katılarak rehber } \\
\text { eşliğinde) seyahat etmeyi severim. }\end{array}$} & Kadın & 367 & 4,29 & 384,47 & 141100 & \multirow{2}{*}{73572} & \multirow{2}{*}{$-2,429$} & \multirow{2}{*}{0,015} \\
\hline & Erkek & 440 & 4,41 & 420,29 & 184928 & & & \\
\hline \multirow{2}{*}{ Bağımsız seyahat etmeyi severim. } & Kadın & 367 & 4,27 & 395,57 & 145174 & \multirow{2}{*}{77646} & \multirow{2}{*}{$-1,039$} & \multirow{2}{*}{0,299} \\
\hline & Erkek & 440 & 4,34 & 411,03 & 180854 & & & \\
\hline \multirow{2}{*}{$\begin{array}{l}\text { Tatile gittiğimde aynı yerde tatil } \\
\text { sürem boyunca kalmayı severim. }\end{array}$} & Kadın & 367 & 4,31 & 388,81 & 142695 & \multirow{2}{*}{75167} & \multirow{2}{*}{$-1,894$} & \multirow{2}{*}{0,058} \\
\hline & Erkek & 440 & 4,42 & 416,67 & 183333 & & & \\
\hline \multirow{2}{*}{$\begin{array}{l}\text { Tatile gittiğimde kısa süreli } \\
\text { konaklamalarla farklı yerler görmeyi } \\
\text { severim. }\end{array}$} & Kadın & 367 & 4,23 & 420,44 & 154302 & \multirow{2}{*}{74706} & \multirow{2}{*}{$-1,974$} & \multirow{2}{*}{0,048} \\
\hline & Erkek & 440 & 4,09 & 390,29 & 171726 & & & \\
\hline \multirow{2}{*}{$\begin{array}{l}\text { Tatil için gideceğim yerin mutlaka } \\
\text { konaklama için geniş seçeneklere } \\
\text { sahip olması gerekmektedir. }\end{array}$} & Kadın & 367 & 4,30 & 398,54 & 146263 & \multirow{2}{*}{78735} & \multirow{2}{*}{$-0,673$} & \multirow[b]{2}{*}{0,501} \\
\hline & Erkek & 440 & 4,31 & 408,56 & 179765 & & & \\
\hline \multirow{2}{*}{$\begin{array}{l}\text { Tatil yeri seçerken mutlaka internette } \\
\text { düşündüğüm yer ile ilgili araştırma } \\
\text { yaparım. }\end{array}$} & Kadın & 367 & 4,62 & 415,50 & 152487 & \multirow[b]{2}{*}{76521} & \multirow[b]{2}{*}{$-1,551$} & \multirow{2}{*}{0,121} \\
\hline & Erkek & 440 & 4,52 & 394,41 & 173541 & & & \\
\hline \multirow{2}{*}{$\begin{array}{l}\text { Tatilden dönüşte hem kendime hem } \\
\text { de yakınlarıma mutlaka hatıra eşyası } \\
\text { satın alırım. }\end{array}$} & Kadın & 367 & 4,40 & 437,00 & 160378 & \multirow{2}{*}{68630} & 4017 & \\
\hline & Erkek & 440 & 4,08 & 376,48 & 165650 & & $-4,011$ & 0,000 \\
\hline Tatil yaptı̆̆ım yerde sosyal medya & Kadın & 367 & 4,53 & 443,02 & 162587 & 66421 & -4.965 & 0.000 \\
\hline aracılığ ile payl & Erkek & 440 & 4,13 & 371,46 & 163441 & 00421 & $-4,90 J$ & 0,000 \\
\hline
\end{tabular}

Katılımcıların cinsiyetlerine göre Amasya'ya ilişkin görüşlerinin farklılaşıp farklılaşmadığını belirlemek için Mann-Whitney U testi yapılmıştır. İlgili analiz sonuçları Tablo 9'da verilmiştir.

Tablo 9 incelendiğinde, "Amasya'nın güvenli bir destinasyon olduğunu düşünüyorum" maddesi için erkeklerin lehine $(\mathrm{z}=-2,065, \mathrm{p}<.05)$, "Ĕ̆ger Karadeniz'e seyahat edersem Amasya'ya uğramadan dönmek istemem" maddesi için kadınların lehine istatistiksel açıdan anlamlı farklılık olduğu görülmektedir ( $\mathrm{z}=-3.737$, $\mathrm{p}<.01)$.

Tabloda yer alan maddelere verilen cevapların ortalamaları incelendiğinde en yüksek ortalamaların "Amasya hakkında olumlu bir imaja sahibim" ve "Tarihi zenginliği yüksek bir destinasyon olduğunu düşünüyorum" maddelerinde olduğu, en düşük ortalamanın ise "Amasya'nın yeterince tanıtıldığını düşünüyorum" maddesinde olduğu görülmektedir.

Tablo 9: Amasya'ya İlişkin Görüşlerin Cinsiyete Göre Değişimi

\begin{tabular}{|c|c|c|c|c|c|c|c|c|}
\hline Maddeler & Cinsiyet & $\mathbf{N}$ & Ortalama & $\begin{array}{c}\text { Sira } \\
\text { Ortalaması }\end{array}$ & $\begin{array}{c}\text { Sira } \\
\text { Toplamı }\end{array}$ & $\mathbf{U}$ & $\mathbf{Z}$ & $\mathbf{p}$ \\
\hline \multirow{2}{*}{$\begin{array}{l}\text { Amasya hakkında olumlu bir imaja } \\
\text { sahibim. }\end{array}$} & Kadın & 367 & 4,20 & 388,76 & 142673,5 & \multirow{2}{*}{75145,5} & \multirow{2}{*}{$-1,874$} & \multirow{2}{*}{0,061} \\
\hline & Erkek & 440 & 4,28 & 416,71 & 183354,5 & & & \\
\hline \multirow{2}{*}{$\begin{array}{l}\text { Amasya'nın güvenli bir destinasyon } \\
\text { olduğunu düşünüyorum. }\end{array}$} & Kadın & 367 & 3,94 & 386,52 & 141854,5 & \multirow{2}{*}{74326,5} & \multirow{2}{*}{$-2,065$} & \multirow{2}{*}{0,039} \\
\hline & Erkek & 440 & 4,08 & 418,58 & 184173,5 & & & \\
\hline \multirow{2}{*}{$\begin{array}{l}\text { Amasya'da Camii, türbe, tarihi eser } \\
\text { gibi bina ve yapıların çok sayıda } \\
\text { olduğunu düşünüyorum. }\end{array}$} & Kadın & 367 & 3,95 & 403,09 & 147932,5 & \multirow{2}{*}{80404,5} & \multirow{2}{*}{$-0,107$} & \multirow{2}{*}{0,915} \\
\hline & Erkek & 440 & 3,97 & 404,76 & 178095,5 & & & \\
\hline \multirow{2}{*}{$\begin{array}{l}\text { Tarihi zenginliği yüksek bir } \\
\text { destinasyon olduğunu düşünüyorum }\end{array}$} & Kadın & 367 & 4,12 & 402,35 & 147661 & \multirow{2}{*}{80133} & \multirow{2}{*}{$-0,196$} & \multirow{2}{*}{0,844} \\
\hline & Erkek & 440 & 4,15 & 405,38 & 178367 & & & \\
\hline \multirow{2}{*}{$\begin{array}{l}\text { Ulaşımı kolay bir destinasyon } \\
\text { olduğunu düşünüyorum }\end{array}$} & Kadın & 367 & 3,08 & 402,37 & 147671,5 & \multirow{2}{*}{80143,5} & \multirow{2}{*}{$-0,185$} & \multirow{2}{*}{0,853} \\
\hline & Erkek & 440 & 3,09 & 405,36 & 178356,5 & & & \\
\hline
\end{tabular}




\begin{tabular}{|c|c|c|c|c|c|c|c|c|}
\hline \multirow{2}{*}{$\begin{array}{l}\text { Amasya'nın muhafazakâr bir yer } \\
\text { olduğunu düşünüyorum. }\end{array}$} & Kadın & 367 & 3,28 & 414,22 & 152020,5 & \multirow{2}{*}{ 76987,5 } & \multirow{2}{*}{$-1,164$} & \multirow{2}{*}{0,244} \\
\hline & Erkek & 440 & 3,16 & 395,47 & 174007,5 & & & \\
\hline \multirow{2}{*}{$\begin{array}{l}\text { Amasya'da konaklama tesisleri bulma } \\
\text { konusunda sıkıntı yaşamayacağımı } \\
\text { düşünüyorum. }\end{array}$} & Kadın & 367 & 3,51 & 396,32 & 145448 & \multirow{2}{*}{77920} & \multirow{2}{*}{$-0,891$} & \multirow{2}{*}{0,373} \\
\hline & Erkek & 440 & 3,59 & 410,41 & 180580 & & & \\
\hline \multirow{2}{*}{$\begin{array}{l}\text { Amasya'yı ziyaret etsem bile uzun } \\
\text { süre konaklamayacağımı } \\
\text { düşünüyorum. }\end{array}$} & Kadın & 367 & 3,78 & 414,38 & 152077 & \multirow{2}{*}{76931} & \multirow{2}{*}{$-1,201$} & \multirow{2}{*}{0,230} \\
\hline & Erkek & 440 & 3,69 & 395,34 & 173951 & & & \\
\hline \multirow{2}{*}{$\begin{array}{l}\text { Amasya'nın yeterince tanıtıldığını } \\
\text { düşünüyorum. }\end{array}$} & Kadın & 367 & 1,97 & 396 & 4,5 & \multirow{2}{*}{77816,5} & \multirow{2}{*}{$-0,946$} & \multirow{2}{*}{0,344} \\
\hline & rkek & 440 & 2,06 & 410 & & & & \\
\hline \multirow{2}{*}{$\begin{array}{l}\text { Tatil planlarım arasında Amasya } \\
\text { hiçbir zaman yer almaz }\end{array}$} & $\operatorname{adin}$ & 36 & 3,4 & 397 & & \multirow{2}{*}{ 78296,5 } & \multirow{2}{*}{$|-0,766|$} & \multirow{2}{*}{0,444} \\
\hline & rkek & 440 & 3,52 & 409,55 & 3,5 & & & \\
\hline \multirow{2}{*}{$\begin{array}{l}\text { Önümüzdeki } 3 \text { yıl içerisinde } \\
\text { Amasya'yı ziyaret etme planım var. }\end{array}$} & Kadın & 367 & 3,32 & 411,5 & 151021 & \multirow{2}{*}{77987} & \multirow{2}{*}{$-0,858$} & \multirow{2}{*}{0,391} \\
\hline & Erkek & 440 & 3,22 & 397,74 & 175007 & & & \\
\hline \multirow{2}{*}{$\begin{array}{l}\text { Amasya'yı sadece bir tur kapsamında } \\
\text { günübirlik olarak ziyaret etmeyi } \\
\text { düşünürüm. }\end{array}$} & Kadın & 367 & 3,50 & 408,95 & 150085,5 & \multirow{2}{*}{ 78922,5 } & \multirow{2}{*}{$-0,568 \mid$} & \multirow{2}{*}{0,570} \\
\hline & Erkek & 440 & 3,45 & 399,87 & 175942,5 & & & \\
\hline \multirow{2}{*}{$\begin{array}{l}\text { Amasya'yı ziyaret eden tanıdıklarım } \\
\text { var ve onlardan olumlu bilgiler aldım. }\end{array}$} & Kadın & 367 & 3,47 & 412,59 & 151420,5 & \multirow{2}{*}{77587,5} & \multirow{2}{*}{$-0,983$} & \multirow{2}{*}{0,326} \\
\hline & Erkek & 440 & 3,37 & 396,84 & 174607,5 & & & \\
\hline \multirow{2}{*}{$\begin{array}{l}\text { Eğer Karadeniz'e seyahat edersem } \\
\text { Amasya'ya uğramadan dönmek } \\
\text { istemem. }\end{array}$} & Kadın & 367 & 3,80 & 436,47 & 160185,5 & \multirow{2}{*}{68822,5} & \multirow{2}{*}{$-3,737$} & 0.0 \\
\hline & Erkek & 440 & 3,50 & 376,91 & 165842,5 & & & \\
\hline & Kadın & 367 & 3,56 & 406,39 & 149144 & 798 & -0.2 & 07 \\
\hline & Erkek & 440 & 3,51 & 402,01 & 176884 & r & $0,2+1$ & \\
\hline
\end{tabular}

\section{SONUÇ}

Yapılan literatür taraması destinasyonun turistlerin gözündeki var olan imajlarının, destinasyon seçimlerinde etkili olduğunu ortaya koymaktadır. Destinasyon imajı ile ilgili ulusal ve uluslararası literatürde birçok çalışma olmasına rağmen bu çalışma Amasya'yı daha önce hiç ziyaret etmeyenlerin gözünden destinasyon imajını ortaya çıkartmayı amaçlaması açısından önemli görülmektedir. Hazırlanan anket formu 807 katılımcıya yüz yüze ve elektronik ortamda uygulanmış ve bulgular elde edilmiştir. Çalışma sonuçlarının Amasya'nın turistik bir destinasyon olarak pazarlanması ve ziyaretçi sayısının arttırılması için destinasyondaki tüm turizm paydaşlarına önemli ipuçları vereceği düşünülmektedir.

Çalışmaya katılanların Amasya denilince akıllarına gelen ilk şeyin "Amasya Elması" $(\%$ 59,6) olduğu saptanmıştır. Bu sonuç; Amasya'nın insanların zihninde henüz turistik bir destinasyon olarak yer etmediği hatta tarımsal faaliyetlerin yoğun olarak yapıldığ 1 bir yerleşim yeri olarak yer aldığını göstermektedir. Bilinilirliği fazla olan Amasya elması imaj çalışmalarında kullanılabilir ancak insanları Amasya'ya seyahat etmeye yöneltecek unsurlara tanıtımda ağırlık verilmelidir.

Amasya'yı daha önce hiç ziyaret etmeyenlere uygulanan anketin sonuçlarına göre katılımcılar ziyaret etmemelerine en önemli gerekçe olarak Amasya hakkında yeterli bir bilgiye sahip olmamalarını göstermişlerdir. Bununla birlikte \% 86,6 gibi büyük bir çoğunluğu da son bir yıl içerisinde Amasya ile ilgili herhangi bir tanıtım materyaline rastlamadıklarını belirtmişlerdir. Destinasyonların rekabet güçlerini artırmadaki en önemli aracın tanıtım faaliyetleri olduğu düşünüldüğünde Amasya'da turizm paydaşlarının bu konuda eksik kaldıkları söylenebilir.

Katılımcıların \% 50,7'si tatilden öncelikli beklentilerinin yeni yerler keşfetme isteği olduğunu belirtmişlerdir. Bu durum Amasya hakkında yeterli bilgi sahibi olmadıkları için ziyaret etmeyen katılımcıları çekmek için bir avantaja çevrilebilir. Oluşturulmak istenen imaj özellikleri temelinde yapılacak tanıtım, pazarlama ve markalama çalışmalarından çok hızlı ve verimli sonuçlar elde edilebilir.

Amasya'yı ziyaret etmeme sebebi olarak belirtilen; ulaşımın kolay olmaması, Amasya hakkında yeteri kadar bilgi sahibi olunmaması, ilgi çekici bir destinasyon olarak görülmemesi ve popüler bir destinasyon olarak değerlendirilmemesinin katılımcıların tatilden öncelikli beklentilerine göre anlamlı farklılık gösterdiği tespit edilmiştir. Tatilden öncelikli beklentisi yeni yerler keşfetmek olan potansiyel ziyaretçilerin ulaşımı kolay, hakkında fikir sahibi oldukları ve ilgi çekici yerlere gitmeye öncelik vermeleri oldukça doğal bir yaklaşımdır.

Cinsiyete göre katılımc1ların turizme ilişkin görüşlerinde "Tatil yeri belirlerken daha önce gitmediğim yerlere öncelik veririm", "Tatile gittiğimde kusa süreli konaklamalarla farkl yerler görmeyi severim", "Tatilden dönüsste hem kendime hem de yakınlarıma mutlaka hatıra eşyası satın alırım" ve "Tatil yaptığım 
yerde sosyal medya aracılı̆̆ ile paylaşımda bulunurum" maddeleri için kadınların lehine istatistiksel açıdan anlamlı farklılık olduğu tespit edilmiştir.

Bununla birlikte verilen cevapların ortalamaları incelendiğinde en yüksek ortalamanın "Tatil için seçeceğim yer ile ilgili $T V$, gazete, sosyal medya vb. ortamlarda yapılan tanitımlar üzerimde olumlu bir izlenim bırakır" ve "Tatil yeri seçerken mutlaka internette düşündügü̈m yer ile ilgili araştırma yaparım" maddelerinde olduğu görülmektedir. Dolayısıyla Amasya ile ilgili internet ve sosyal medyada yapılacak olan tanıtım faaliyetlerinin potansiyel ziyaretçileri etkileme ihtimalinin oldukça yüksek olduğu söylenebilir. Özellikle de kadınların sosyal medyada sıklıkla takip ettikleri kişi veya sayfalarla yapılacak işbirlikleri vasıtasıyla gerçekleştirilecek tanıtım faaliyetleri çok daha etkili olacaktır.

Cinsiyete göre katılımcıların Amasya'ya ilişkin görüşlerinde "Amasya'nın güvenli bir destinasyon olduğunu düşünüyorum" maddesi için erkeklerin lehine, "Eğer Karadeniz'e seyahat edersem Amasya'ya uğramadan dönmek istemem" maddesi için kadınların lehine istatistiksel açıdan anlamlı farklılık olduğu tespit edilmiştir. Erkeklerin genellikle belirlenen destinasyonlara yapılacak olan seyahatlerin organizasyonundan sorumlu oldukları düşünüldügünde gidilecek yerin güvenlik ile ilgili unsurlarına dikkat ettikleri söylenebilir. Amasya'nın imaj çalışmalarında hem asayiş hem de sağlık açısından güvenilir bir destinasyon olduğuna vurgu yapmak avantaj sağlayabilir.

Katılımcıların Amasya ile ilgili görüşlerinin öğrenilmeye çalışıldığı maddelere verilen cevapların ortalamaları incelendiğinde en yüksek ortalamaların "Amasya hakkında olumlu bir imaja sahibim" ve "Tarihi zenginliği yüksek bir destinasyon olduğunu düşünüyorum” maddelerinde olduğu, en düşük ortalamanın ise "Amasya'nın yeterince tanitıldığını düşünüyorum" maddesinde olduğu tespit edilmiştir. Bu ve önceki tespitlerden Amasya'nın ziyaret edilmemesinin Amasya ile ilgili insanların kafasında yer alan olumsuz bir imajdan kaynaklanmadığı tam aksine olumlu düşüncelerin olduğu ancak yeterince tanıtılmadığ için fazla bilgi sahibi olunmamasından kaynaklandığı açıktır.

Turizm pazarlamasında başarı; sadece tek bir işletmenin, yerel yönetimlerin veya kişilerin tek başlarına sonuç elde edebilecekleri bir durum değildir. İçerisinde yerel halkın da olduğu tüm paydaşların katkısı gerekmektedir. Amasya ile ilgili yapılacak olan imaj çalışmalarının belirli bir plan dahilinde, akademisyenlerden teorik, sektör duayenlerinden ise pratik önerileri alınarak, karar alıcılar ile koordinasyon içerisinde yürütülmesi, sürekli kontrol edilmesi, değerlendirilmesi ve geliştirilmesi gerekmektedir.

\section{Sektöre Yönelik Öneriler}

Amasya'ya gelecek ve memnun bir şekilde ikamet ettikleri yerlere dönecek olan turistlerin hem yakın çevrelerine hem de sosyal medya aracılığıyla daha fazla kişiye Amasya'yı tavsiye etmeleri ve henüz gelmemiş olanların gözünde olumlu imaj oluşumuna katkıda bulunmaları alacakları hizmetlerin kalitesi ve çeşitliliği ile ilişkilidir. Bu yüzden destinasyonda yer alan turizm işletmelerinin personel ve hizmet kalitesine önem vermeleri, olabilecek şikayetleri hızlı bir şekilde çözüme kavuşturmaları, turistlerin gerçek anlamda evlerinde hissetmelerini sağlayacak aktivitelere ağırlık vermeleri önerilmektedir.

\section{Araştırmacılara Yönelik Öneriler}

$\mathrm{Bu}$ çalışma Amasya'yı hiç ziyaret etmeyenlere uygulanan bir anketin sonuçlarını içermektedir. Araştırmacılar gelecek çalışmalarda ziyaret edenler ile etmeyenlerin destinasyon imajlarını karşılaştırdıkları bir çalışma yapabilecekleri gibi Amasya ile benzer özelliklere sahip Türkiye'den veya Dünyadan başka bir destinasyonun imajı ile Amasya imajının karşılaştırıldığı bir çalışma yapabilirler. 


\section{KAYNAKÇA}

Akyurt, Hakan ve Lütfi Atay, (2009) “Destinasyonda İmaj Oluşturma Süreci”, Aksaray Üniversitesi İIBBF Dergisi, Cilt 1 , Sayı 1.

Assaker, Guy, Vincenzo Esposito Vinzi ve O'Connor, Peter , (2011), "Examining the Effect of Novelty Seeking, Satisfaction and Destination Image on Tourists' Return Pattern :A Two Factor, Non Linear Latent Growth Model", Tourism Management, 32, s.890-901.

Boone, H. N. ve Deborah Boone, (2012) "Analyzing Likert Data", The Journal of Extension, 50, 1-5.

Ceylan, Seyhan, (2011) “Destinasyon Marka İmajı ve Pamukkale Yöresinde Bir Uygulama”, Uluslararası İktisadi ve İdari İncelemeler Dergisi, Yı1 4, Say1 7.

Cherifi, Barbara, Andrew Smith, Robert Maitland ve Nancy Stevenson, (2014) "Destination Image of Non Visitors", Anals of Tourism Research 49, s.190-202.

Choi, Jeong Gil, Tamara Tkachenko ve Shomir Sil, (2011) “ On the Destination Image of Korea by Russian Tourists”, Tourism Management, 32, s. 193-194.

Creswell, J. W., (2012) Educational Research: Planning, Conducting, and Evaluating Quantitative and Qualitative Research (4th ed.), Pearson, Boston.

Demirel, Mustafa (2014), "Burdur Kent İmajı: Mehmet Akif Ersoy Üniversitesi Öğrencileri Üzerine Bir Alan Araştırması", Mehmet Akif Ersoy Üniversitesi Sosyal Bilimler Enstitüsü Dergisi, 6 (10), s.230-241.

Firat, Aytekin ve Fatma Kömürcüoğlu, (2015), "Muğla Şehir Markası ve İmaj Algısı; Muğla Sitkı Koçman Üniversitesi Öğrencileri Üzerine Bir Alan Araştırması”, Yönetim Bilimleri Dergisi, 13 (26), s.285-304.

Gallarza, Martina, Ireene Gil Saura ve Haydee Calderon Garcia, (2002), "Destination Image:Towards a Conceptual Framework", Annals of Tourism Management, 29(1), s.56-78.

Hosany, S., Ekinci, Y. ve M.Uysal (2006) "Destination Image and Destination Personality: An Application of Branding Theories to Tourism Places", Journal of Business Research, 59(5), s.638-642.

Jani, Dev ve Yeong-Hyeon Hwang, (2011) "User-generated Destination Image Through Weblogs: A Comparison of Preand Post-visit Images", Asia Pacific Journal of Tourism Research, 16: 3, s. 339-356.

Kavacık, Mustafa, Saadet Zafer ve Mehmet Emin İnal, (2012) "Turizmde Destinasyon Markalamasi: Alanya Örneği”, Erciyes Üniversitesi İktisadi ve İdari Bilimler Fakültesi Dergisi, Sayı: 39, s. 169-192.

Ketter, Eran, (2016), "Destination Image Restoration on Facebook: The Case Study of Nepal's Gurkha Earthquake", Journal of Hospitality and Tourism Management, 8, s.66-72.

Kim, Hong-Bumm ve Sanggun Lee, (2015) "Impacts of City Personality and Image on Revisit Intention", International Journal of Tourism Cities, 1(1), s.50-69.

Murphy, Laurie, (2000) "Australia's Image as a Holiday Destination- Perceptions of Backpacker Visitors", Journal of Travel \& Tourism Marketing, 8:3, s. 21-45.

O'Leary, Sinead ve Jim Deegan, (2005), "Ireland's Image as a Tourism Destination in France: Attribute Importance and Performance", Journal of Tourism Research, 43(3), s.247-256

Pekyaman, Asuman, (2008) “Turistik Satın Alma Davranışında Destinasyon İmajının Rolü Afyonkarahisar Bölgesinde Bir Araştırma”, Doktora Tezi, Afyon Kocatepe Üniversitesi, Sosyal Bilimler Enstitüsü, Afyon.

Song, Hanqun ve Cathy H. C. Hsu, (2013) "The Image of Taiwan as a Travel Destination: Perspectives From Mainland China", Journal of Travel \& Tourism Marketing, 30:3, s.253-271.

Şahin, Şafak ve Seyhmus Baloglu, (2011) "Brand Personality and Destination Image of Istanbul”, Anatolia, 22 (1), s. 69-88.

Yamaç, Zeynep ve Burhanettin Zengin, (2015) "Sakarya Destinasyonunun İmaj Algısına Yönelik Bir Çalışma”, İşletme Bilimi Dergisi, Cilt:3 Sayı:2.

Yaraşlı, Göker Yarkın, (2007) "Destinasyon İmajı ve Trabzon Yöresine Dönük Bir Çalışma", Yüksek Lisans Tezi, Başkent Üniversitesi, Sosyal Bilimler Enstitüsü, Ankara.

Zhang, Hongmei; Fu, Xiaoxiao; Cai, Liping A.; Lu, Lin, (2014) "Destination Image and Tourist Loyalty: A MetaAnalysis", Tourism Management, 40, s.213-223.

https://www.oka.org.tr/Documents/86AMASYA\%20MARKA\%20KENT\%20STRATEJIK\%20KALKINMA\%20PLA NI.pdf, erişim tarihi: 27.11.2019 